INVITED REVIEW ARTICLE

\title{
高齢者肺癌の外科治療
}

\author{
佐治 久 $1 \cdot$ 丸島秀樹 $1 \cdot$ 宮澤知行 1 ・ \\ 木村祐之 1 酒井寛貴 1 ・ 小島宏司 1
}

\section{The Current Status and Future Directions of Surgical Strategies for the Treatment of Elderly Lung Cancer Patients}

\author{
Hisashi Saji1; Hideki Marushima1; Tomoyuki Miyazawa1; \\ Yusuke Kimura1; Hiroki Sakai1; Koji Kojima1 \\ ${ }^{1}$ Department of Chest Surgery, St. Marianna University School of Medicine, Japan.
}

\begin{abstract}
Due to changes in social conditions including the recent rapid medical progress, we now have become an aging society, in the developed nations in particular, and the ratios of primary lung cancer among the cause of death have thus steadily increased in recent years. As a result, surgical treatment for lung cancer, which is the goal of a radical cure, is not limited due to only chronological age worldwide. Several clinical studies have attemped to establish a risk scoring system for the selection of elderly patients who are indicated to undergo surgical treatment. According to these studies, the importance of performing comprehensive geriatric assessments in elderly patients has been suggested. In addition, the influence of long-term overall survival and the ratio of other causes of death in association with cancer treatment have become important to establish the optimal surgical treatment from the viewpoint of social life maintenance. Currently, several surgical clinical studies for these purpose have been conducted and the results of such studies are highly awaited.
\end{abstract}

(JJLC. 2020;60:298-304)

KEY WORDS — Elderly patient, Lung cancer, Risk scoring, Long-term survival, Comprehensive geriatric assessment

Corresponding author: Hisashi Saji.

要旨一一近年の急速な医療の進歩を含む社会情勢の変 化により，特に先進諸国においては高齢化社会を迎え， この状況の中で死亡原因に占める原発性肺癌の割合は 年々増加している．高龃者肺癌外科治療はその安全性か ら，世界的にも暦年齢だけで根治を目指した外科治療が 制限されることはない。高齢者肺癌外科治療を選択する 上でリスクスコアリングシステムを構築する数々の研究 が報告され，高齢者ならではの総合機能評価の重要性が
示唆されている．問題となるのはがん治療における長期 予後と他病死割合に加えて, 社会生活維持の観点からの 至適外科治療法の確立である。これらを目的とした外科 系臨床試験が現在, 計画・遂行されており, その結果が 期待される.

索引用語——高齢者, 肺癌, リスクスコアリング, 長期 予後, 高齢者総合機能評価

\section{はじめに}

近年の急速な医療の進歩を含む社会情勢の変化によ り，特に先進諸国においては高齢化社会を迎え，この状 況の中で死亡原因に占める悪性腫瘍の割合は年々増加し
ている. Global Cancer Statistics 2018 によると, 肺癌は世 界的にも罹患者数（全症例の $11.6 \%$ ), 死亡者数（全症例 の $18.4 \%$ ）ともに第 1 位の悪性新生物である. 1 本邦で は, 最新の「がんの統計 ‘19」(がん研究振興財団 $)^{2}$ によ ると部位別がん罹患者数および死亡者数では, 肺癌はそ 


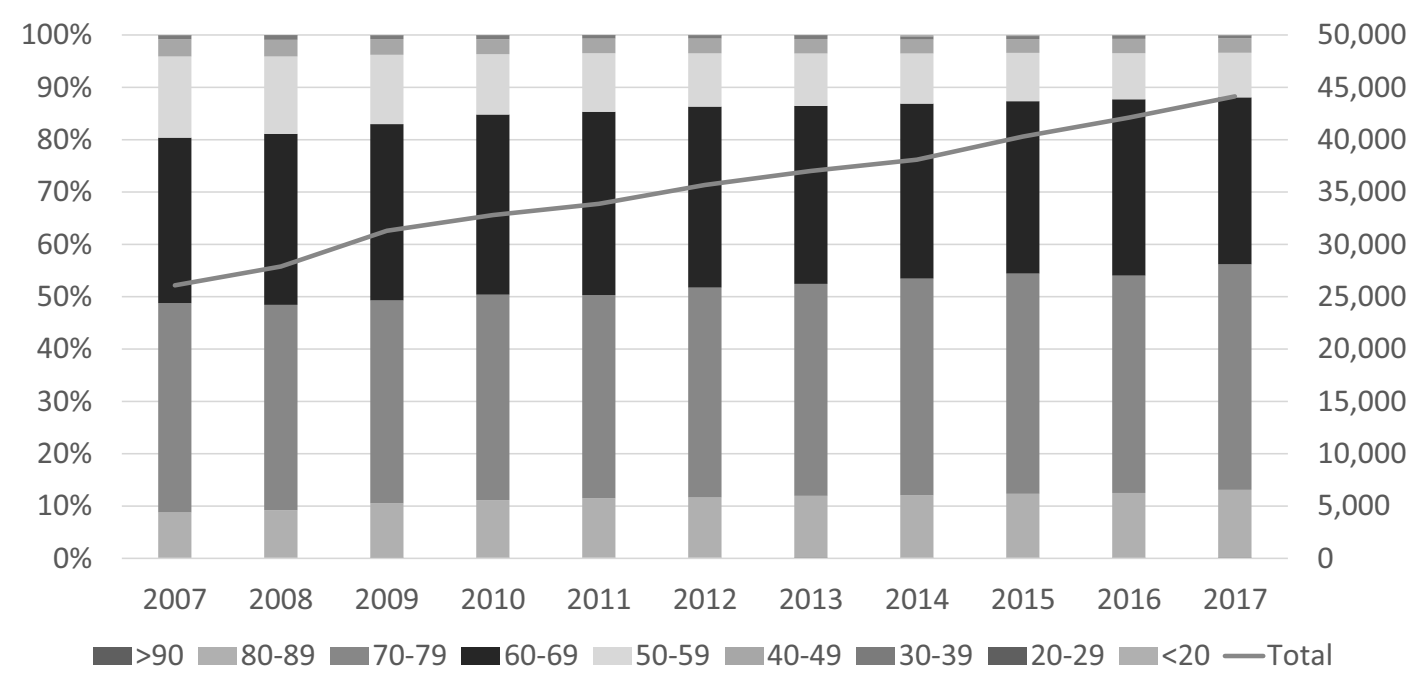

Figure 1. The trends of the lung cancer patient population for thoracic surgeries over the years in Japan based on the Annual report by the Japanese Association for Throacic Surgery.

れぞれ 130,424 人 $(2016$ 年), 74,328 人 $(2018$ 年) と年々 増加しており，1990 年代後半より現在に至るまで一貫し て第 1 位を占めている。.さらに年齢階級別がん死亡部位 別内訳 (2018 年) を見ると, 男性では 70 歳以上では肺癌 と前立腺癌の割合が多くなり, 女性では 40 歳代で多い乳 癌, 婦人科癌は, 高齢になるほどその割合は小さくなり, 消化器系と肺癌の割合が大きくなっている. 外科治療に 扔いても 2020 年に報告された日本胸部外科学会学術調 查 2017 年次報告 3 によると, 原発性肺癌に対して年間 44,140 例の手術が行われ，その年齢別内訳では 6 割弱 (56\%) が 70 歳以上，さらに 80 歳を超える超高齢者に対 しても $13 \%$ に施行されており,この傾向は年々増加の一 途をたどっている (Figure 1)。ささらに，数\%ではあるが 90 歳を超える肺癌患者にもある一定の割合で根治を目 指した外科的治療が選択されている現状である.

一般に高齢者の多くは, 循環器・呼吸器疾患や糖尿病 を代表とする生活習慣病をはじめ身体機能の低下をきた す併存疾患が複数存在し, 加えて認知機能の低下を伴う 場合も認められる.上って高齢者肺癌に打ける治療方針 の決定には, がんの進行度と個々の暦年齢のみならず併 存疾患や認知機能など総合的に評価することが求められ ている.ささらに，昨今の多様性社会では，本人の人生観 や価值観が反映されるべきであり，医療行政・医療経済 の観点からも, 特に高齢者に扔いては同時に QOL, ADL や, 要介護度に代表される社会生活の質にかかる事項が 担保されるか否かが, 治療方針決定の際には重要視され るようになってきている.

本稿では高齢者肺癌に対する外科治療の現状と将来の 外科治療戦略について最新の知見と方向性を述べるとと
もに, 現在, 計画・遂行されている臨床試験に関しても 情報提供をする。

\section{1. 高齢者肺癌治療選択において}

はじめに「高齢者」の定義に触れておく，厚生労働省 が発表する平成 30 年（2018 年）簡易生命表 4 によると, 男女の平均寿命はそれぞれ 81.09 歳, 87.26 歳と過去最高 を更新した，日常生活に制限のない健康寿命と平均寿命 には約 10 年のギャップが見られるが, 80 歳時における 平均余命もそれぞれ 9.06 年と 11.91 年と 10 年前後は期 待される.さらに 90 歳になってもそれぞれ 4.33 年, 5.66 年と約 5 年の平均余命が期待されるというのが本邦の現 状である.「高齢者」を暦年齢で定義すると 70 歳以上と することが多いが, 65 歳以上 (WHO 提唱) や, 75 歳以 上（後期高齢者）とすることもある. 前述の如く, 本邦 で施行されている原発性肺癌手術件数の 6 割弱が既に 70 歳以上に実際に行われている現状から, 治療方針決定 において, 必ずしも特殊な集団とは言い難い. よって本 稿では肺癌診療ガイドライン（日本肺癌学会）における 定義である 75 歳以上を高齢者として, さらに 80 歳以上 の超高齢者をも対象に議論することとする.

前述の如く, これら高齢者の大きな特徵は心機能・呼 吸機能・肝機能・腎機能などの重要臟器の機能低下に加 え, 筋力などの生理機能の低下, 糖尿病をはじめとした 代謝内分泌系の機能異常や免疫機能の低下に加えて, 認 知機能の減弱といった様々な身体的 - 心理的脆弱性を伴 うことである.こうした高齢者肺癌に対する治療法の選 択に際しては，様々な因子を考虑する必要があるが，第 一義的にはその治療介入により生存期間の延長が期待さ 
Table 1. Summary of the Survival Outcomes for Surgical Resection in Octogenarians with Lung Cancer

\begin{tabular}{|c|c|c|c|c|c|c|c|}
\hline Authors & Journal and Year & $\mathrm{N}$ & Stage & $\begin{array}{l}\text { Limited } \\
\text { resection }\end{array}$ & $\begin{array}{l}\text { Operation } \\
\text { related } \\
\text { death }\end{array}$ & $\begin{array}{l}5 \text { years } \\
\text { survival } \\
\text { rate }\end{array}$ & $\begin{array}{c}\text { Other } \\
\text { causes } \\
\text { death }\end{array}$ \\
\hline Aoki $\mathrm{T}$, et al & $\begin{array}{c}\text { Eur J Cardiothorac Surg } \\
2003\end{array}$ & 49 & $\begin{array}{l}\text { IA: } 55 \% \\
\text { IB: } 45 \%\end{array}$ & $\begin{array}{l}\text { No lymph } \\
\text { node } \\
\text { resection: } \\
55.1 \%\end{array}$ & $2.0 \%$ & $\begin{array}{c}\text { Lymph node } \\
\text { resection: } \\
55.5 \% \\
\text { No: } 44.8 \%\end{array}$ & ND \\
\hline Ikeda $\mathrm{N}$, et al & Respirology 2007 & 73 & $\begin{array}{c}\text { I: } 82 \% \\
\text { II: } 14 \% \\
\text { IIIA: } 4 \%\end{array}$ & $\begin{array}{c}\text { Sublober } \\
\text { resection: } \\
31.3 \%\end{array}$ & $4.1 \%$ & $\begin{array}{c}\text { I: } 57.4 \% \\
\text { II: } 88.9 \% \\
\text { III: } 18.2 \%\end{array}$ & ND \\
\hline $\begin{array}{l}\text { Dominguez-Ventura A, } \\
\text { et al }\end{array}$ & $\begin{array}{l}\text { Eur J Cardiothorac Surg } \\
2007\end{array}$ & 294 & $\begin{array}{l}\text { I: } 66 \% \\
\text { II: } 14 \% \\
\text { III: } 17 \% \\
\text { IV: } 3 \%\end{array}$ & $\begin{array}{c}\text { Sublober } \\
\text { resection: } \\
26.2 \%\end{array}$ & $6.3 \%$ & $\begin{array}{l}\text { All: } 34 \% \\
\text { IA: } 48 \% \\
\text { IB: } 39 \% \\
\text { IIA: } 17 \% \\
\text { IIB: } 23 \% \\
\text { IIIA: } 9 \% \\
\text { IIIB: } 0 \%\end{array}$ & $69 \%$ \\
\hline Brokx HA, et al & J Thorac Oncol 2007 & 124 & $\begin{array}{c}\text { I-II: } 93 \% \\
\text { III: } 5 \% \\
\text { IV: } 2 \%\end{array}$ & $\begin{array}{c}\text { Sublober } \\
\text { resection: } \\
5 \%\end{array}$ & $4 \%$ & $47 \%$ & ND \\
\hline Okami J, et al & J Thorac Oncol 2009 & 367 & $\begin{array}{l}\text { IA: } 58 \% \\
\text { IB: } 42 \%\end{array}$ & $\begin{array}{c}\text { Sublober } \\
\text { resection: } \\
33 \%\end{array}$ & $1.4 \%$ & $\begin{array}{l}\text { IA: } 62.0 \% \\
\text { IB: } 47.2 \%\end{array}$ & $51 \%$ \\
\hline Port JL, et al & Ann Thorac Surg 2011 & 121 & $\begin{array}{c}\text { I: } 65 \% \\
\text { II: } 25 \% \\
\text { III: } 10 \%\end{array}$ & $\begin{array}{c}\text { Video-assist- } \\
\text { ed thoracic } \\
\text { surgery: } \\
33 \%\end{array}$ & $1.7 \%$ & $\begin{array}{c}\text { I: } 69.6 \% \\
\text { II: } 35.6 \% \\
\text { III: } 18.2 \%\end{array}$ & ND \\
\hline Nakao M, et al & Jpn J Clin Oncol 2020 & 70 & $\mathrm{cNO}$ & $\begin{array}{l}\text { Video-assist- } \\
\text { ed thoracic } \\
\text { surgery } \\
\text { without } \\
\text { lymph node } \\
\text { resection }\end{array}$ & $\begin{array}{c}\text { No } \\
\text { in-hospital } \\
\text { death }\end{array}$ & $72.8 \%$ & $10 \%$ \\
\hline
\end{tabular}

れることであり，第二義的には治療介入による QOL や ADL といった社会生活機能の維持が, 治療に際して予測 される合併症のリスクを上回ると推定されることであ る.

\section{2. 高齢者肺癌に対する外科治療の現状}

Table 1 には 80 歳以上の高歯者肺癌に対する外科治 療の成績に関する, これまでの報告を示す. 5-13 本邦にお いて大規模な報告は, 2007 年の Okami らの肺癌登録合 同委員会 (Japanese Joint Committee of Lung Cancer Registry）の調査研究である.1999年に登録された 13,344 例の肺癌外科手術症例のうち 80 歳以上の臨床病 期 I 期早期肺癌 367 例を対象とした研究報告である。手
術関連死亡は $1.4 \%$ であり, 本邦全症例における $0.6 \%$ と 比べて有意に高いとは言えず，他の報告でも概ね同様の 傾向が認められる。しかし，長期予後では他病死割合が 80 歳以上では 3 割程度認められ, 周術期管理には問題は ないが，長期には他病死する割合が多く，これは併存疾 患の管理に加え肺癌外科手術の侵襲が高齢者の身体機能 に与える影響は少なくないことを示し, この傾向は他の 報告でも同様に散見されている.

\section{3. 高齢者肺癌に対する外科治療戦略の考え方}

そもそもがん治療における外科治療の位置づけは, 根 治を目指した治療法でありハイリスクハイリターンが原 則である。一方，前述の如く，高齢者がん患者に対する 


\begin{tabular}{|l|l|l|l|}
\hline \begin{tabular}{|l|l|} 
Elderly patients \\
with lung cancer
\end{tabular} & $\begin{array}{l}\text { Small-size early } \\
\text { lung cancer }\end{array}$ & Early lung cancer & $\begin{array}{l}\text { Locally advanced } \\
\text { lung cancer }\end{array}$ \\
\hline Low risk group & $\begin{array}{l}\text { Sublober } \\
\text { resection } \\
\text { v.s. SBRT }\end{array}$ & $\begin{array}{l}\text { Lobectomy } \\
\text { vs Sublober } \\
\text { v.s. SBRT }\end{array}$ & $\begin{array}{l}\text { Extended } \\
\text { resection } \\
\text { V.s. } \\
\text { Chemotherapy } \\
\text { and or RT } \\
\text { followed by ICI }\end{array}$ \\
\hline High risk group & $\begin{array}{l}\text { Sublober } \\
\text { resection v.s. } \\
\text { SBRT }\end{array}$ & $\begin{array}{l}\text { Sublober } \\
\text { v.s. SBRT }\end{array}$ & $\begin{array}{l}\text { Chemotherapy } \\
\text { and or RT } \\
\text { followed by ICI } \\
\text { v.s. BSC }\end{array}$ \\
\hline
\end{tabular}

SBRT=stereotactic body radiotherapy, $\mathrm{RT}=$ radiotherapy, $\mathrm{ICl}=\mathrm{imm}$ uno-check point inhibitor, BSC=best supportive care

Figure 2. Current surgical strategies for elderly patients with lung cancer.

治療方針決定の医療従事者側の基本的な考元方は，第一 義的には生存期間の延長であり，第二義的には QOL と ADL の維持が治療に際して予測される合併症のリスク を上回ることである.よって高齢者の場合には，根治を 得られたが日常生活が維持できなくなった場合や，ハイ リスクである手術が引き金となり他病死の割合が増える 場合には，その治療方法の是非が問われることになる。

Figure 2 には筆者が考える肺癌進行度に抢ける治療方 針決定の現状を示す.

2020 年以降には小型早期肺癌に対する至適縮小切除 術を決定する各種臨床試験（JCOG0802/WJOG4607L, JCOG0804/WJOG4507L, JCOG1211, CALGB140503)の 結果が公表される予定であるが，こと高齢者小型早期肺 癌を対象とした場合には低侵襲治療を選択される傾向は 既にある.よって、リスクの大小に関わらず高齢者小型 早期肺癌に対しては縮小切除もしくは定位放射線治療が 選択されることにほほ異論はない.さらに, 元々ハイリ スクな高齢者に対して低侵襲治療を選択することは医療 従事者側も患者家族側もほほ納得をするところである.

また,リスクのない局所進行肺癌患者に対して集学的治 療に何らかの手術を加えるかどうかの是非は高齢者に 限った問題ではない，我々呼吸器外科医が治療戦略を明 確にしなければならない対象は, リスクのない根治切除 可能な高齢者肺癌に対して社会生活を損なわず，かつ生 命予後の延長も十分に期待される標準術式の構築であ り, その解答を科学的に検証する臨床試験が求められて いる (Figure 2 矢印(2))。問題は，その大前提となる高齢 者肺癌に扔ける，さらにその治療方針決定に直結するリ スク評価の基準が定まっていないことである（Figure 2 矢印(1).

\section{4. 高齢者肺癌治療における総合リスク評価}

これらの高齢者のリスクについては主に併存疾患, 全 身状態, 認知機能を単独に, もしくは組み合わせてスコ アリングして評価する方法がある.19疾患を因子とし て, その重要度を 6 段階にスコアリングして検討した Charlson Comorbidity Index (CCI) , 5 これらの因子を, 喫煙歴, 飲酒歴に加えて重要疾患を含めた 7 項目に簡便 化した Simplified Comorbidity Score (SCS), 14 血清アル ブミン值と血漿 C 反応性蛋白值をスコアリングして予 後予測を検討した Glasgow Prognostic Score（GPS）, 15 日常生活動作, 認知機能, 社会経済因子などを包括的に 評価する Comprehensive Geriatric Assessment (CGA) 16 などがある、肺癌を含めて各種癌腫での予後因子として の報告はあるが, 肺癌外科領域において治療適応の可否 を決定するシステムは未だ確立しているとは言い難い.

Table 2 には，これまでに報告された 1,000 例を超える 規模の公的機関のレジストリー研究に扔いて, 高龄者肺 癌手術患者を対象とした周術期合併症を予測するリスク スコアリングシステムに関する研究のまとめを示 す.17-19 一般的なリスク因子である性別, 呼吸機能, 病 期, 術式に加えて, 併存疾患を指標とする CCI, SCS や栄養状態を評価する GPS が項目として挙げられてい る. 本邦では高齢者ならではの高齢者総合機能評価 (CGA)の重要性に注目し, 日本呼吸器外科学会学術委員 会企画20として 2015２016 年にかけて 1,019 例に及ぶ 80 歳以上の高齢者肺癌手術症例を前向きに集積し報告 してきた. 多変量解析の結果, Grade 3 以上の有害事象に 相関する独立因子として性別, 記憶力, 血清アルブミン 值, 肺活量 (\%), 糖尿病併存が残り, そのリスク程度か 
Table 2. Summary of the National Registry Studies on the Risk Scoring Systems Identifying the Surgical Outcomes in Elderly Patients with Lung cancer

\begin{tabular}{|c|c|c|c|c|c|c|c|}
\hline Authors and Journal & National registry & Design & $\mathrm{N}$ & Age & Mortality & $\begin{array}{c}\text { Adverse } \\
\text { event }\end{array}$ & Factors \\
\hline $\begin{array}{l}\text { Rueth NM, et al } \\
\text { J Thorac Cardiovasc } \\
\text { Surg } 2012\end{array}$ & $\begin{array}{l}\text { The Surveillance } \\
\text { Epidemiology and } \\
\text { End-Results-Medi- } \\
\text { care linked database } \\
(2000-2005)\end{array}$ & Retrospective & 4,171 & $66-80$ & $4.2 \%$ & $55.8 \%$ & $\begin{array}{l}\text { Higher age [75-80], } \\
\text { sex, CCI, tumor size }\end{array}$ \\
\hline $\begin{array}{l}\text { Detillon DD, et al } \\
\text { Ann Thorac Surg } \\
2018\end{array}$ & $\begin{array}{l}\text { The Dutch Lung } \\
\text { Surgery Audit } \\
\text { database (2013-2014) }\end{array}$ & Retrospective & 2,133 & $\geq 60$ & $2.1 \%$ & $29.9 \%$ & $\begin{array}{l}\text { Sex, FEV } 1.0 \text {, DLCO, } \\
\text { coronary bypass, } \\
\text { COPD, open thoracot- } \\
\text { omy, lobectomy, high- } \\
\text { er age }\end{array}$ \\
\hline $\begin{array}{l}\text { Saji H, et al } \\
\text { Eur J Cardiothorac } \\
\text { Surg } 2018\end{array}$ & $\begin{array}{c}\text { The Japanese } \\
\text { Association for } \\
\text { Chest Surgery } \\
(2015-2016)\end{array}$ & Prospective & 1,019 & $\geq 80$ & $1.0 \%$ & $34 \%$ & $\begin{array}{l}\text { Sex, CGA score, VC, } \\
\text { Alb, DM }\end{array}$ \\
\hline
\end{tabular}

Table 3. Distribution of the Patients and Their Predicted Risk for Severe Postoperative Complications

\begin{tabular}{ccccc}
\hline Score & $\begin{array}{c}\text { Patient } \\
\text { number }\end{array}$ & $\begin{array}{c}\text { Risk observed \% } \\
\text { (predicted) }\end{array}$ & $\begin{array}{c}\text { Frequency observed } \\
\text { (predicted) }\end{array}$ & Patient's risk \\
\hline 0 & 176 & $1.7(2.4)$ & $3(4)$ & Low risk \\
1 & 63 & $4.8(3.3)$ & $3(2)$ & $<5 \%$ \\
2 & 69 & $5.8(4.6)$ & $4(3)$ & Intermediate risk \\
\hline 3 & 223 & $6.3(6.3)$ & $14(14)$ & $5-24 \%$ \\
4 & 109 & $6.4(8.6)$ & $7(9)$ & \\
5 & 122 & $13.9(11.6)$ & $17(14)$ & High risk \\
6 & 74 & $17.6(15.5)$ & $13(11)$ & $\geq 25 \%$ \\
7 & 32 & $12.5(20.3)$ & $4(7)$ & $5(6)$ \\
\hline 8 & 22 & $22.7(26.2)$ & $2(2)$ & \\
9 & 5 & $40.0(33.2)$ & .
\end{tabular}

Risk scoring system $=3$ (Gender: male) +2 (CGA75: memory: yes) +2 (Alb: $<3.8 \mathrm{ng}$ / $\mathrm{ml})+1$ (\%VC: $\leq 90)+1$ (SCS: diabetes mellitus: yes).

ら点数化して発症割合を計算するリスクスコアリングシ ステムが構築された (Table 3$)$. 本研究は大規模に前向き に集積された最初の臨床研究であり，高齢者総合機能評 価を正確に評価するためには後ろ向き研究には限界があ り，とても意義深い研究であると言える.

\section{5. 高齢者肺癌外科治療における総合リスク評価と 長期予後との関連}

現状の実臨床において，前述の如く手術関連死亡率は 既に低く, 高歯者肺癌外科治療における我々の周術期マ ネージメントはほぼ確立されているといっても過言では ない. 問題となるのは長期予後と他病死割合であり，周 術期合併症と長期予後との関連についての研究も数々報 告されている.21-25 仮説としては, 周術期に重篤な有害 事象を発症した症例では心肺機能をはじめ重要臓器の機 能低下により他病死が増え，その影響は高齢者になるほ
ど強く現れると考えられる。前述の日本呼吸器外科学会 学術調査研究でも同様の傾向が認められ, 術前に行われ るリスクスコアリングにてハイリスクとなったグループ (一部改変)では他グループと比べて有意に他病死割合が 多くなり, それらは術後 2 年以内に多く認められている (Figure 3).ささらに肺癌死割合も多く,さらに無再発生存 期間とも相関が認められ，これらの結果は重篤な術後有 害事象が免疫機能低下に及ぼす影響がその一因であると 示唆される。

\section{6. 高齢者肺癌に対する計画・遂行中の外科関連の 臨床試験}

高齢者肺癌だからという理由で, 腫瘍学的に手控える 傾向にある低侵襲手術をそのまま応用して良いかは議論 のあるところであり, やはり科学的検証により明確にす ることが肝要である。前述の Figure 2 に示すように，高 


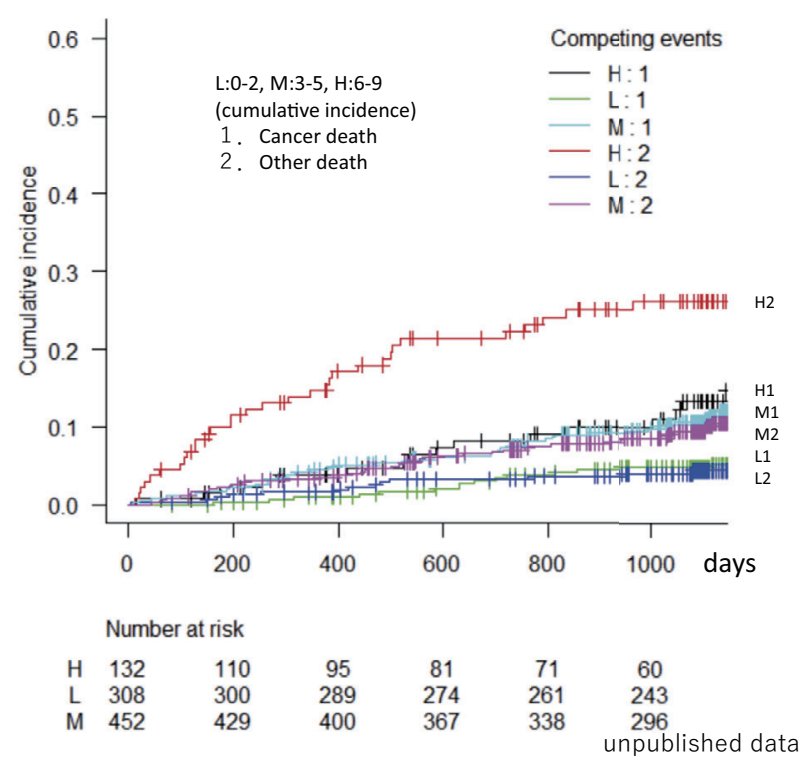

Figure 3. Current surgical strategies for elderly patients with lung cancer.

齢者肺癌患者における術前リスクスコアリングシステム の構築 (矢印(1))はほほ確立されてきており, 次のステッ プとして我々が標準術式に耐えられると考える対象に対 して, それが長期予後の観点から, さらに社会生活維持 の観点からも妥当性があるかどうかを科学的に検証する 比較試験が考えられ, 現在, JCOG 肺がん外科グループに おいて計画されている。縮小手術としては肺切除範囲の 縮小とリンパ節郭清範囲の縮小の 2 つが考えられ, 前者 はJCOG0802/WJOG4607Lの結果によりその縮小切除 術式が決定され, 後者は系統的リンパ節郭清と選択的リ ンパ節郭清を比較したJCOG1413において縦隔リンパ 節転移形式が明確になれば縦隔リンパ節郭清を省略しう る対象が絞られ，高齢者に応用する臨床試験が考えられ る.

また,これまでに高齢者肺癌術後の社会生活維持の観 点から計画された臨床試験も数々報告があり, 評価指標 としては EORTC QLQ-C30, EORTC QLQ-LC13, DASS21, SF-36v2 が用いられている. 26-30 本邦では 75 歳以上 の高齢者肺癌手術患者を対象に老研式 IADL, EQ-5D$5 \mathrm{~L}$, 要介護度の変化を社会生活維持の評価指標として用 いた前向きコホート研究 JCOG1701A が遂行され, 2020 年 5 月に登録を完了している.

\section{おわりに}

これまで述べてきたように 75 歳以上, もしくは 80 歳 を超える高齢者肺癌に対しても，その手術関連死亡率の 低さから, 既に安全性は担保されており, 暦年齢のみで
手術適応が制限されることはない. さらに，実臨床にお ける我々呼吸器外科医の現在の外科的治療選択基準には 数々のコホート研究からも理にかなった成績であり, あ る一定の妥当性はあると考えられる．高歯令肺癌患者に対 する至適手術療法の是非は, 重篤な合併症リスクと期待 余命の推定, がん疾患による死亡と他病死発生割合, $\mathrm{QOL} \cdot \mathrm{ADL}$ 低下に伴う社会生活維持のリスク, 代替治 療法の有効性, 本人の人生観と家族の希望などを総合し て決定されるべきである，将来，さらに進む超高齢化社 会に向けて, これらの課題に対して科学的観点から情報 提供しうる臨床試験の結果が期待され, それらを計画・ 遂行し続けることは, 専門家集団である我々呼吸器外科 医の責務であると考えられる.

本論文内容に関連する著者の利益相反：佐治 久 [研究費 助成金などの総額 $]$ AMED 委託研究開発費, [奨学 (奨励) 寄 附金などの総額]大鵬薬品工業株式会社, 日本イーライリリー 株式会社, NISSHA 株式会社, アストラゼネカ株式会社, 中 外製薬株式会社

\section{REFERENCES}

1. Bray F, Ferlay J, Soerjomataram I, Siegel RL, Torre LA, Jemal A. Global cancer statistics 2018: GLOBOCAN estimates of incidence and mortality worldwide for 36 cancers in 185 countries. CA Cancer J Clin. 2018;68:394-424.

2. がん研究振興財団. がんの統計 ‘19. 2020.

3. Committee for Scientific Affairs, The Japanese Association for Thoracic Surgery, Shimizu H, Okada M, Tangoku A, Doki Y, Endo S, et al. Thoracic and cardiovascular surgeries in Japan during 2017 : Annual report by the Japanese Association for Thoracic Surgery. Gen Thorac Cardiovasc Surg. 2020;68:414-449.

4. 厚生労働省. 平成 30 年簡易生命表の概況. https://ww w.mhlw.go.jp/toukei/saikin/hw/life/life18/index.html

5. Aoki T, Tsuchida M, Watanabe T, Hashimoto T, Koike $\mathrm{T}$, Hirono $\mathrm{T}$, et al. Surgical strategy for clinical stage I non-small cell lung cancer in octogenarians. Eur J Cardiothorac Surg. 2003;23:446-450.

6. Port JL, Kent M, Korst RJ, Lee PC, Levine MA, Flieder $\mathrm{D}$, et al. Surgical resection for lung cancer in the octogenarian. Chest. 2004;126:733-738.

7. Ikeda N, Hayashi A, Iwasaki K, Kajiwara N, Uchida O, Kato H. Surgical strategy for non-small cell lung cancer in octogenarians. Respirology. 2007;12:712-718.

8. Dominguez-Ventura A, Cassivi SD, Allen MS, Wigle DA, Nichols FC, Pairolero PC, et al. Lung cancer in octogenarians: factors affecting long-term survival following resection. Eur J Cardiothorac Surg. 2007;32:370-374.

9. Brokx HA, Visser O, Postmus PE, Paul MA. Surgical treatment for octogenarians with lung cancer: results from a population-based series of 124 patients. $J$ Thorac Oncol. 2007;2:1013-1017.

10. Okami J, Higashiyama M, Asamura H, Goya T, Koshiishi $\mathrm{Y}$, Sohara Y, et al. Pulmonary resection in patients aged 
80 years or above with clinical stage I non-small cell lung cancer: prognostic factors for overall survival and risk factors for postoperative complications. J Thorac Oncol. 2009;4:1247-1253.

11. Port JL, Mirza FM, Lee PC, Paul S, Stiles BM, Altorki NK. Lobectomy in octogenarians with non-small cell lung cancer: ramifications of increasing life expectancy and the benefits of minimally invasive surgery. Ann Thorac Surg. 2011;92:1951-1957.

12. Ito H, Nakayama H, Yamada K, Yokose T, Masuda M. Outcomes of lobectomy in 'active' octogenarians with clinical stage I non-small-cell lung cancer. Ann Thorac Cardiovasc Surg. 2015;21:24-30.

13. Nakao M, Ichinose J, Matsuura Y, Okumura S, Mun M. Outcomes after thoracoscopic surgery in octogenarian patients with clinical N0 non-small-cell lung cancer. Jpn J Clin Oncol. 2020; hyaa061.

14. Colinet B, Jacot W, Bertrand D, Lacombe S, Bozonnat $\mathrm{MC}$, Daurès JP, et al. A new simplified comorbidity score as a prognostic factor in non-small-cell lung cancer patients: description and comparison with the Charlson's index. Br J Cancer. 2005;93:1098-1105.

15. McMillan DC, Forrest LM, O'Gorman P, Angerson WJ, McArdle CS. Performance status of male and female advanced cancer patients is independently predicted by mid-upper arm circumference measurement. Nutr Cancer. 2002;42:191-193.

16. Stuck AE, Siu AL, Wieland GD, Adams J, Rubenstein LZ. Comprehensive geriatric assessment: a meta-analysis of controlled trials. Lancet. 1993;342:1032-1036.

17. Rueth NM, Parsons HM, Habermann EB, Groth SS, Virnig BA, Tuttle TM, et al. Surgical treatment of lung cancer: predicting postoperative morbidity in the elderly population. J Thorac Cardiovasc Surg. 2012;143:1314-1323.

18. Detillon DD, Veen EJ. Postoperative Outcome After Pulmonary Surgery for Non-Small Cell Lung Cancer in Elderly Patients. Ann Thorac Surg. 2018;105:287-293.

19. Saji H, Ueno T, Nakamura H, Okumura N, Tsuchida M, Sonobe M, et al. A proposal for a comprehensive risk scoring system for predicting postoperative complications in octogenarian patients with medically operable lung cancer: JACS1303. Eur J Cardiothorac Surg. 2018;53: 835-841.

20. Saji H, Ueno T, Nakamura H, Committee for Scientific Affairs, The Japanese Association for Chest Surgery.
Prospective observational cohort study of postoperative risk and prognosis scoring for elderly patients with medically operable lung cancer (JACS1303). Gen Thorac Cardiovasc Surg. 2016;64:634-635.

21. Rueth NM, Parsons HM, Habermann EB, Groth SS, Virnig BA, Tuttle TM, et al. The long-term impact of surgical complications after resection of stage I nonsmall cell lung cancer: a population-based survival analysis. Ann Surg. 2011;254:368-374.

22. Lugg ST, Agostini PJ, Tikka T, Kerr A, Adams K, Bishay E, et al. Long-term impact of developing a postoperative pulmonary complication after lung surgery. Thorax. 2016;71:171-176.

23. Nojiri T, Hamasaki T, Inoue M, Shintani Y, Takeuchi Y, Maeda H, et al. Long-Term Impact of Postoperative Complications on Cancer Recurrence Following Lung Cancer Surgery. Ann Surg Oncol. 2017;24:1135-1142.

24. Wang S, Li X, Li Y, Li J, Jiang G, Liu J, et al. The longterm impact of postoperative pulmonary complications after video-assisted thoracic surgery lobectomy for lung cancer. J Thorac Dis. 2017;9:5143-5152.

25. Okada S, Shimada J, Kato D, Tsunezuka H, Teramukai S, Inoue M. Long-Term Prognostic Impact of Severe Postoperative Complications After Lung Cancer Surgery. Ann Surg Oncol. 2019;26:230-237.

26. Burfeind WR Jr, Tong BC, O'Branski E, Herndon JE, Toloza EM, D'Amico TA, et al. Quality of life outcomes are equivalent after lobectomy in the elderly. $J$ Thorac Cardiovasc Surg. 2008;136:597-604.

27. Ferguson MK, Parma CM, Celauro AD, Vigneswaran WT. Quality of life and mood in older patients after major lung resection. Ann Thorac Surg. 2009;87:1007-1013.

28. Salati M, Brunelli A, Xiumè F, Refai M, Sabbatini A. Quality of life in the elderly after major lung resection for lung cancer. Interact Cardiovasc Thorac Surg. 2009;8:7983.

29. Balduyck B, Hendriks J, Lauwers P, Sardari Nia P, Van Schil P. Quality of life evolution after lung cancer surgery in septuagenarians: a prospective study. Eur J Cardiothorac Surg. 2009;35:1070-1075.

30. Schulte T, Schniewind B, Walter J, Dohrmann P, Küchler T, Kurdow R. Age-related impairment of quality of life after lung resection for non-small cell lung cancer. Lung Cancer. 2010;68:115-120. 